\title{
Porphyrin xanthene amides: anchoring distal H-bonding in heme models
}

\author{
Chi K. Chang ${ }^{\mathrm{a}, *}$, Nilkamal Bag ${ }^{\mathrm{a}}$, Baomin Guo ${ }^{\mathrm{a}}$, Shie-Ming Peng \\ a Department of Chemistry, Michigan State University, East Lansing, MI 48824, USA \\ ${ }^{\mathrm{b}}$ Department of Chemistry, National Taiwan University, Taipei, Taiwan, ROC
}

Received 15 February 2003; accepted 22 February 2003

This paper is dedicated to the memory of the late Professor Gerald T. Babcock

\begin{abstract}
Distal H-bonding to axial ligand is strategically introduced in metalloporphyrin models by modifying porphyrin xanthene acid in which the carboxyl proton is preferentially H-bonded to the xanthene oxygen. Xanthene carboxamide is able to deliver intramolecular H-bonding and simultaneously lock into a well-defined conformation. Multipoint recognition of ligand is demonstrated in an amidinium-acetate-Zn porphyrin complex, mimicking a structural feature found in sulfite reductase.

(C) 2003 Elsevier Science B.V. All rights reserved. Distal H-bonding to axial ligand is strategically introduced in metalloporphyrin models by modifying porphyrin xanthene acid in which the carboxyl proton is preferentially H-bonded to the xanthene oxygen. Xanthene carboxamide is able to deliver intramolecular H-bonding and simultaneously lock into a well-defined conformation. Multipoint recognition of ligand is demonstrated in an amidinium-acetate-Zn porphyrin complex, mimicking a structural feature found in sulfite reductase.
\end{abstract}

(C) 2003 Elsevier Science B.V. All rights reserved.

Keywords: Amidinium; Hydrogen bond; Metalloporphyrin; Mimics; Reductase

\section{Introduction}

Fundamental bioreductions of small molecules catalyzed by heme enzymes often require noncovalent interactions such as H-bonding. The substrate binding site (so-called distal site) of numerous heme proteins is exquisitely designed to perform electrophilic or general acid catalysis, with positively charged residues providing a strong polarizing environment and high effective proton concentration to facilitate reductive bond cleavage. For example, in horseradish peroxidase, the presence of a protonated arginine in concert with a distal histidine is the centerpiece of the 'push-pull' effect resulting in the heterolytic $\mathrm{O}-\mathrm{O}$ bond cleavage of the iron-bound peroxide. In P450 monooxygenases, while a distal polar group seems to be missing from the immediate surround-

\footnotetext{
* Corresponding author. Tel.: +517-355-9715; fax: +1-517-3531753.

E-mail address: chang@ust.hk (C.K. Chang).
}

ing, other polar residues within the heme pocket may form a proton relay network to aid the $\mathrm{O}-\mathrm{O}$ bond cleavage. In $a a_{3}$ type cytochrome oxidases, as well as in the $c d_{1}$ system, the presence of tyrosine $-\mathrm{OH}$ group is believed to play a major role in $\mathrm{O}_{2}$ reduction . Recent $\mathrm{X}$-ray crystallographic studies of sulfite reductase also revealed a remarkable array of positively charged residues juxtaposing the coordinating anion. The multiple H-bonds presumably are needed for enhancing the substrate binding and weakening the short and stable $\mathrm{S}-\mathrm{O}$ bonds through polarization and dissipation of ionic character during reduction. Given such importance, the construction of structural and functional models to mimic the protonhanging distal site has been one of the focal points of many recent studies. We hae reported such models based on either porphyrin naphthoic acid or a ' $\mathrm{C}$-clamp porphyrin in which a carboxylic acid or amide oerhangs the binding site, producing dramatic results in $\mathrm{O}_{2}$ binding [8,9][811][7][6][5][4][3][1,2] $]^{\mathrm{b}}$. Another aspect of this work focused on proton-coupled electron transfer (PCET) reactions 
mediated by salt bridge complexes where directionality of PCET can be manipulated [12-14]. An offshoot of this research theme has resulted in a porphyrin xanthene acid in which the xanthene pillar is employed to 'hang' a carboxylic acid above the porphyrin ring [11]. In the present report we wish to focus on the xanthene carboxamide; the purpose here is to highlight its unique utility as a platform for probing the distal H-bonding effect in heme enzyme models. The bulk of this study was carried out in the mid 1990s and described in a thesis [15].

\section{Results and discussion}

Rebek and coworkers first demonstrated the utility of xanthene-4,5-dicarboxylic acid as molecular host, and discussed the difference between the acid and amide [16]. There is a tendency for the acid to form intramolecular $\mathrm{H}$-bond with the xanthene oxygen and thus, less 'sticky' toward substrate as compared with the amide. Shipps and Rebek also reported the synthesis of the first porphyrin bis-xanthene acid starting with a xanthene monoaldehyde-monoester [17]. We used a different approach and focused on the synthesis of single-armed porphyrin xanthene acid (Scheme 1). The readily available xanthene-4,5-dicarboxaldehyde (2) [18] reacted in ethanol with 2 equiv. of pyrrole (3) in the presence of $\mathrm{HCl}$ and the resultant formyl dipyrrylmethane (4) was treated with hydoxylamine- $\mathrm{HCl}$ in refluxing $98 \%$ for-

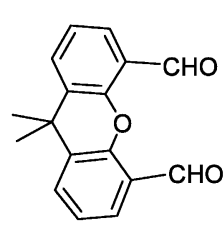

2

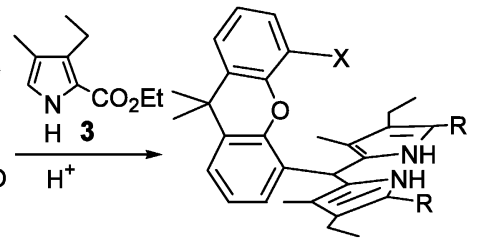

$4 \mathrm{X}=\mathrm{CHO}, \mathrm{R}=\mathrm{CO}_{2} \mathrm{Et}$ $5 \mathrm{X}=\mathrm{CN}, \mathrm{R}=\mathrm{CO}_{2} \mathrm{Et}$ $6 \mathrm{X}=\mathrm{CO}_{2} \mathrm{H}, \mathrm{R}=\mathrm{H}$
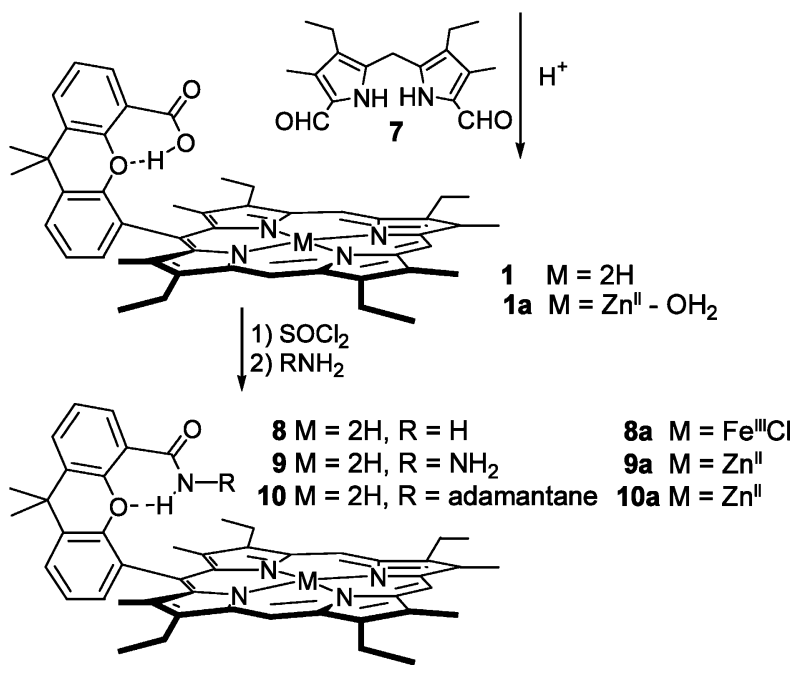

Scheme 1. mic acid to convert the formyl group to the nitrile (5). This was followed by a one-step decarboxylation in refluxing ethylene glycol containing $\mathrm{NaOH}$ to give the dipyrrylmethane (6), giving excellent yields of over $85 \%$ in each step. Compound $\mathbf{6}$ was then condensed with the diformyl dipyrrylmethane (7) in dry methanol containing catalytic amount of perchloric acid to afford the porphyrin xanthene acid (8), purified as the zinc complex by column chromatography (yield $30 \%$ ).

Crystallographic analysis (Fig. 1(a)) of the Zn complex of $\mathbf{8}$ showed, as expected, the acid proton $\mathrm{H}$-bonded to the xanthene oxygen $(\mathrm{O} 2 \cdots \mathrm{O} 42.531 \AA)$ rendering it unavailable for the axial ligand. In this case, however, an axial aqua ligand is within $\mathrm{H}$-bonding distance (O4 . . O $12.754 \AA$ ) to the carboxylic oxygen. The aqua molecule and the carboxylic acid moiety are perfectly coplanar with the flat xanthene pillar which sits perpendicular to the porphyrin plane. To make available a proton for the ligand, the porphyrin amide (9) was synthesized and the $\mathrm{Fe}(\mathrm{III}) \mathrm{Cl}$ complex of which has the crystal structure shown in Fig. 1(b). Indeed, the amide proton is pushing onto the bulky iron-bound chloride $(\mathrm{Fe}-\mathrm{Cl} 2.199 \AA$, N3 …Cl $3.170 \AA$ ) causing the $\mathrm{Fe}-\mathrm{Cl}$ bond to slightly tilt by about $5.2^{\circ}$ from the heme axis.

To test the flexibility of the xanthene porphyrin scaffold, several amides have been prepared. The hydrazide (9) is interesting in that the terminal nitrogen forms a direct $\mathrm{N}-\mathrm{Zn}$ bond $(2.247 \AA$ ) by simultaneously pulling the xanthene bridge toward the porphyrin ring and the $\mathrm{Zn}$ metal out of the plane (Fig. 1(c)). ${ }^{1}$ Coordination between $\mathrm{sp}^{3}$-nitrogen and metalloporphyrins is normally weak and unremarkable, as compared with $\pi$-base. This unique model makes it possible to study a clean five-coordinate heme-hydrazide complex. The ability of the xanthene amide to place a wellaimed functional group or moiety near or at the porphyrin center seems unsurpassed since the rigid peptide linkage has restricted freedom of rotation due to the locking $\mathrm{H}$-bonding at the xanthene oxygen.

Perhaps the most dramatic result is seen in the 1adamantylcarboxamide (10) where molecular modeling suggested the bulky adamantane cannot be accommodated without severely distorting the structure if the amide linkage is to keep its anticipated locking position. Alternatively, of course, the peptide bond may rotate out $180^{\circ}$ to alleviate the steric strain, but loosing the $\mathrm{H}$ bonding. The structure of a square planar $\mathrm{Zn}$ complex of $\mathbf{1 0}$ (Fig. 1(d)) showed that this is not to be the case. There is a folding along the xanthene center ridge and a slightly twisted carboxamide moiety maintaining $\mathrm{H}$ bonding distance to the xanthene (N5 …OO1 $2.757 \AA$ ). This arrangement attests to the uniqueness of the

${ }^{1}$ Zn out-of-N 4 plane distance: 0.253 A (Fig. 1(a)) vs. $0.296 \AA$ A (Fig. $1(c))$. 
(a)

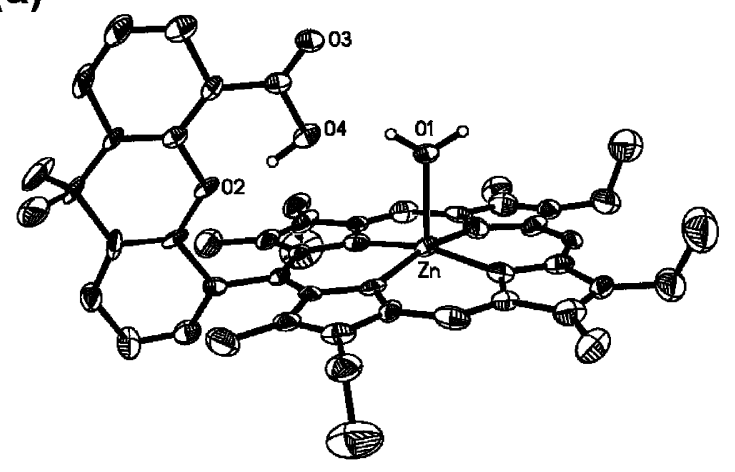

(c)

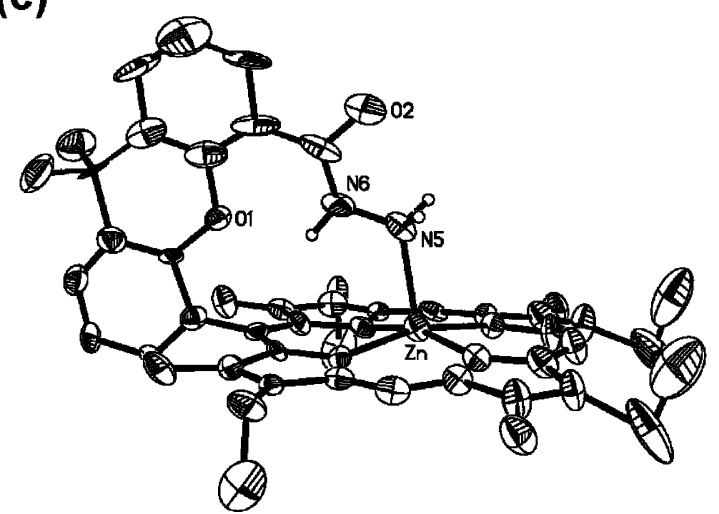

(b)

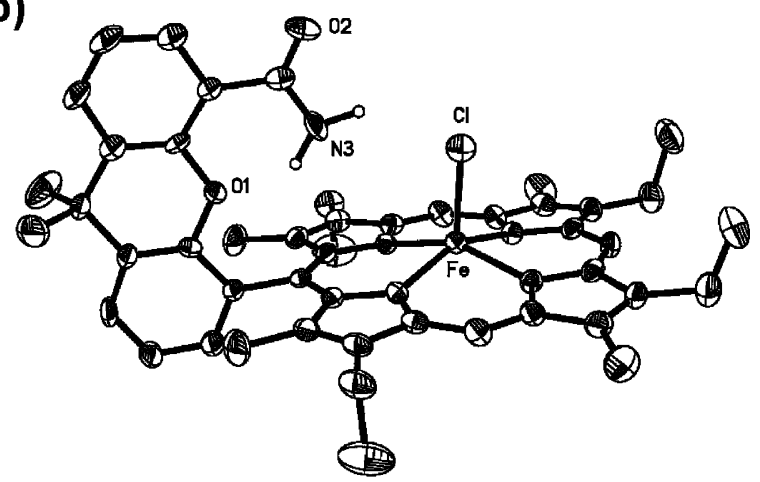

(d)

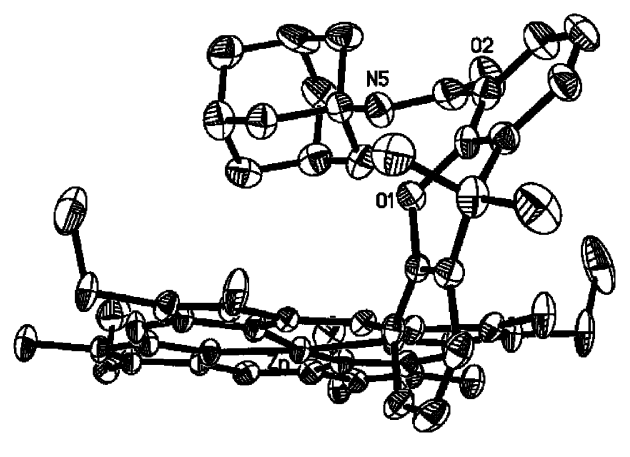

Fig. 1. Crystal structures of (a) 1a, $\mathrm{Zn}$ (II) $-\mathrm{OH}_{2}$ complex of 1, (b) 8a, Fe(III)-Cl complex of 8, (c) 9a, Zn(II) complex of 9, and (d) 10a, Zn(II) complex of 10. In all cases, the intramolecular hydrogen-bond with the xanthene oxygen plays a crucial role in restricting the conformation. Except for (d) in which the xanthene plane shows butterfly folding along with other distortions to accommodate the bulky adamantanamide, all others have the xanthene spacer completely flat and perpendicular to the porphyrin plane.

1) $\mathrm{NaBH}_{4}$

4

2) $\mathrm{NaOH}$

3) $7, \mathrm{H}^{+}$

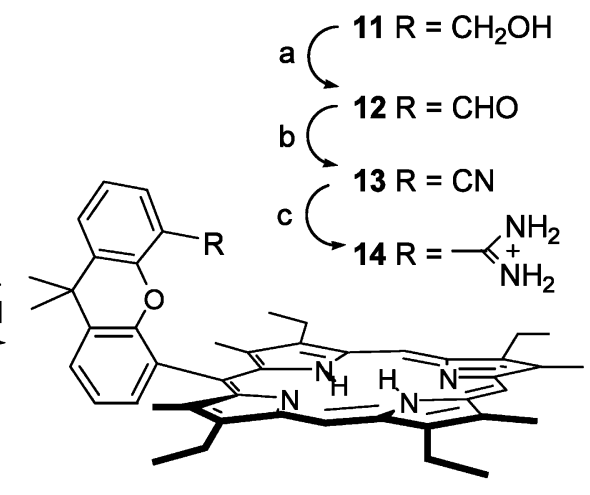

Reagents \& condition: a) $\mathrm{CrO}_{3}$, py, $82 \%$;

b) $\mathrm{H}_{2} \mathrm{NOH}-\mathrm{HCl}, \mathrm{HCO}_{2} \mathrm{H}$, reflux, $95 \%$;

c) i. $\mathrm{Ni}(\mathrm{OAc})_{2}$; ii. $\mathrm{MeAl}(\mathrm{Cl}) \mathrm{NH}_{2}$, toluene; iii. $\mathrm{H}_{2} \mathrm{SO}_{4}, 74 \%$

\section{Scheme 2 .}

xanthene spacer arm in enforcing a predictable conformation for the secondary amide substituent.

The realization of the xanthene amide platform allowed us to introduce multiple $\mathrm{H}$-bonds at the metalloporphyrin coordination site. As shown in Scheme 2, xanthene monoaldehyde (4) was converted to porphyrin monoaldehyde (12) by employing a reac- tion sequence first developed in our laboratory using $\mathrm{CH}_{2} \mathrm{OH}$ as the protecting group for the sensitive aldehyde [19]. The aldehyde was then transformed to the nitrile (13) from which the amidine (14) was obtained by using the Weinreb's amide transfer reagent [20]. The crystal structure of the zinc complex of $\mathbf{1 4}$ revealed a coordinating acetate anion whose formation is undoubtedly aided by the three-point contact as

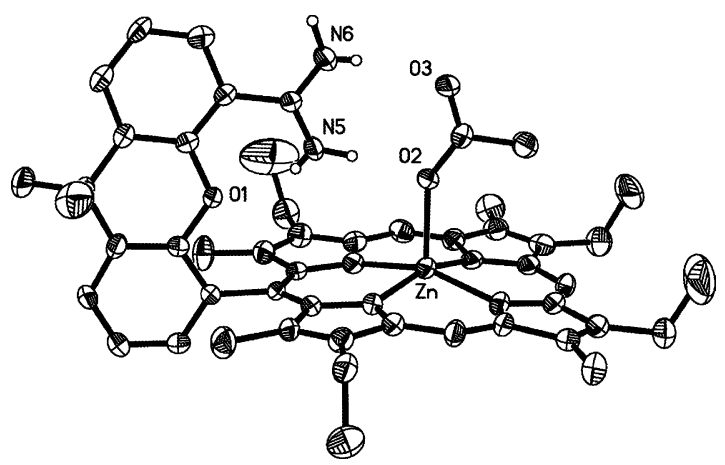

Fig. 2. Solid state structure of $\mathbf{1 4 a}$, the $\mathrm{Zn}-\mathrm{OAc}$ complex of 14; crystals were obtained after heating the porphyrin with $\mathrm{Zn}(\mathrm{OAc})$ in methanol. Normally, acetate cannot compete with methanol in coordinating $\mathrm{Zn}(\mathrm{II})$ porphyrins. Bond length and distance: $\mathrm{Zn}-\mathrm{O} 2$

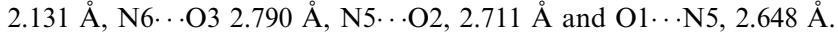


shown in Fig. 2. In the absence of the amidine anchor, acetic acid or acetate anion has a very poor affinity toward $\mathrm{Zn}$ (II) porphyrin and to our knowledge no structure of unassisted acetic acid (or acetate) $\mathrm{Zn}$ porphyrin complex is known. Previously, we have reported the structure of $\mu$-acetato-coupled $\mathrm{ZnN}_{3}-\mathrm{Zn}$ porphyrin [where $\mathrm{N}_{3}=$ bis(2-picolyl)amine] [21]. In that case, the acetate binds to the $\mathrm{Zn}$ porphyrin due to the strong coordination derived from the nonplanar $\mathrm{ZnN}_{3}$ site. The interesting structure realized in this study (Fig. 2) therefore may be considered to be the first model compound to mimic the sulfite reductase-phosphate complex wherein multiple contacts between the anion and protonated arginine have been recognized [7]. Replacement of the zinc with a redox-active metal center should make possible further development of the chemistry of proton-coupled small molecule activation.

\section{Concluding remarks}

We have demonstrated, through careful design and synthesis aided by X-ray crystallographic characterization, that the porphyrin xanthene amide and its derivatives to be a superior platform upon which specific distal hydrogen-bonding can be achieved. The amide functionality can be adapted to give superstructured heme models that are conformationally rigid and well defined. For the purpose of providing distal H-bonding, the xanthene carboxamide should yield a truer 'hangman' porphyrin than the acid of which the proton is less efficient in providing intermolecular $\mathrm{H}$-bonding toward substrate. $^{2}$

\section{Experimental}

Reagents and solvents for synthesis were used as received unless otherwise stated. ${ }^{1} \mathrm{H}$ NMR spectra were recorded on Varian Gemini-300 in $99.9 \% \mathrm{CDCl}_{3}$ with residual $\mathrm{CHCl}_{3}$ as the internal standard set at $7.24 \mathrm{ppm}$. Mass spectra were measured on a VG Trio-1 mass spectrometer for $\mathrm{m} / \mathrm{z}$ less than 1000 or on JEOL HX$110 \mathrm{HF}$ double focusing spectrometer in the FAB MS positive ion detection mode for $\mathrm{m} / \mathrm{z}$ over 1000 . UV-Vis spectra were measured on a Shimadzu 160 spectrometer.

\footnotetext{
${ }^{2}$ The $-\mathrm{COOH} \cdots \mathrm{H}_{2} \mathrm{O} \cdots \mathrm{HO}-\mathrm{Fe}$ description (Ref. [11]) cannot be unambiguously distinguished from $-\mathrm{COO} \cdots \mathrm{H}_{2} \mathrm{O} \cdots \mathrm{H}_{2} \mathrm{O}-\mathrm{Fe}$ due to facile deprotonation of the acid. In the reported structure, the carboxyl $\mathrm{C}-\mathrm{O}$ bond length of 1.295(5) $\AA$, falling short of the threshold of 1.31 $\AA$, is indicative of a carboxylate anion, while in authentic acids such as 1 in Fig. 1(a), the $\mathrm{C}-\mathrm{O}$ distance of 1.39(3) $\AA$ is longer as expected. It would be interesting to test for the purported Fe-hydroxide using amide 8.
}

Infrared spectra were recorded on a Nicolet IR/42 spectrometer.

\subsection{Synthesis of the carboxamide derivatives $(\boldsymbol{8}-10)$}

4.1.1. 5-Formyl-4-\{[5,5'-bis(ethoxycarbonyl) $-4,4^{\prime}-$ diehyl-3,3'-dimethyl-2,2'-dipyrryl]methyl $\}$ - (9,9dimethyl) xanthene (4)

4,5-Diformyl-9,9-dimethylxanthene [18] (522 mg, 2 $\mathrm{mmol})$ was dissolved in anhydrous ethanol $(20 \mathrm{ml})$ at room temperature (r.t.) in the presence of concentrated $\mathrm{HCl}(0.5 \mathrm{ml})$ under argon atmosphere. To this solution was added ethyl 3-ethyl-4-methyl-2-pyrrolecarboxylate (742 mg, $4.1 \mathrm{mmol}$ ) in three portions over a period of 15 min. The solution mixture was refluxed for 45 min under argon. The solution was cooled in a refrigerator for $4 \mathrm{~h}$ and the light yellow crystalline solid was collected by filtration. The filtrate was concentrated and then diluted with water; more solid precipitated and was filtered and thoroughly washed with water to give yellow crystals of 4. The combined yield was $987 \mathrm{mg}(81 \%)$ : m.p. 104$106{ }^{\circ} \mathrm{C}$; MS: $m / z=610$ for $\mathrm{C}_{37} \mathrm{H}_{42} \mathrm{~N}_{2} \mathrm{O}_{6} ;{ }^{1} \mathrm{H}$ NMR $(300$ $\left.\mathrm{MHz}, \mathrm{CDCl}_{3}\right): \delta=10.12(1 \mathrm{H}, \mathrm{s}, \mathrm{CHO}), 8.30(2 \mathrm{H}, \mathrm{br}$, $\mathrm{NH}), 7.65(2 \mathrm{H}, \mathrm{t}), 7.39(1 \mathrm{H}, \mathrm{d}), 7.17-7.06(2 \mathrm{H}, \mathrm{m})$, $6.79(1 \mathrm{H}, \mathrm{d}), 5.99(1 \mathrm{H}, \mathrm{s}$, methane $\mathrm{CH}), 4.21(4 \mathrm{H}, \mathrm{q})$, $2.69(4 \mathrm{H}, \mathrm{q}), 1.80(6 \mathrm{H}, \mathrm{s}), 1.64(6 \mathrm{H}, \mathrm{s}), 1.26(6 \mathrm{H}, \mathrm{t})$, $1.08(6 \mathrm{H}, \mathrm{t})$.

\subsubsection{5-Cyano-4-\{[5,5'-bis(ethoxycarbonyl)-4,4'- diethyl-3,3'-dimethyl-2,2'-dipyrryl Jmethyl\}-(9,9- dimethyl) xantnene (5)}

The above aldehyde 4 (610 $\mathrm{mg}, 1 \mathrm{mmol})$ dissolved in $99 \%$ formic acid $(8 \mathrm{ml})$ was mixed with hydroxylamine hydrochloride ( $75 \mathrm{mg}, 1.1 \mathrm{mmol})$. The resulting mixture was refluxed for $1 \mathrm{~h}$ before being poured onto ice. After the solution was neutralized with $5 \% \mathrm{NaOH}$ solution, the brown solid was collected by filtration to afford 590 mg $(97 \%)$ of 5. MS: $m / z=607.4$ for $\mathrm{C}_{37} \mathrm{H}_{41} \mathrm{~N}_{3} \mathrm{O}_{5}$ : IR $v_{\mathrm{C}=\mathrm{N}} 2236 \mathrm{~cm}^{-1},{ }_{1}^{1} \mathrm{H}$ NMR $\left(300 \mathrm{MHz}, \mathrm{CDCl}_{3}\right): \delta=8.19$ (2 H, br, NH), 7.66-7.51 (2 H, m), $7.40(1 \mathrm{H}, \mathrm{d}), 7.27-$ $6.95(2 \mathrm{H}, \mathrm{m}), 6.68(1 \mathrm{H}, \mathrm{d}), 5.70(1 \mathrm{H}, \mathrm{s}$, methane $\mathrm{CH})$, $4.22(4 \mathrm{H}, \mathrm{q}), 2.70(4 \mathrm{H}, \mathrm{q}), 1.81(6 \mathrm{H}, \mathrm{s}), 1.54(6 \mathrm{H}, \mathrm{s})$, $1.28(6 \mathrm{H}, \mathrm{t}), 1.07(6 \mathrm{H}, \mathrm{t})$.

\subsubsection{Xanthene-porphyrin acid (1)}

The diester dipyrrylmethane $5(500 \mathrm{mg}, 0.82 \mathrm{mmol})$ was decarboxylated and the cyano group was simultaneously hydrolyzed by refluxing overnight in ethylene glycol $(20 \mathrm{ml})$ containing $\mathrm{NaOH}$ solution $(5 \mathrm{ml}, 20 \%)$ under argon atmosphere. The dark color solution was poured into ice water and the resulting yellowish-brown solid was collected by filtration. This decarboxylated dipyrrylmethane (6) and dipyrrylmethane (7) [22] (230 $\mathrm{mg}, 0.81 \mathrm{mmol})$ was dissolved in dry methanol $(60 \mathrm{ml})$ under argon atmosphere. To this mixture $70 \%$ perchloric acid $(0.5 \mathrm{ml})$ was added and the solution was stirred 
at r.t. under argon atmosphere with exclusion of light for $16 \mathrm{~h}$. Then a solution of $\mathrm{NaOAc}(0.5 \mathrm{~g})$ in methanol $(10 \mathrm{ml})$ was added, followed by another solution of $o$ chloranil $(180 \mathrm{mg})$ in methanol $(5 \mathrm{ml})$. After $1 \mathrm{~h}$, the solvent was removed and the residue was taken up in dichloromethane $(20 \mathrm{ml})$ and a solution of zinc acetate $(300 \mathrm{mg})$ in methanol $(5 \mathrm{ml})$ was added. After being stirred for $3 \mathrm{~h}$, the solvent was evaporated and the residue was purified by chromatography (silica gel, dichloromethane) to give $182 \mathrm{mg}(29 \%)$ pure product of 1a. UV-Vis (dichloromethane): $\lambda_{\max }$ (rel. int.) $=406$ (0.668), 536 (0.033), 570 (0.032); MS: $m / z=792.7$ for $\mathrm{C}_{48} \mathrm{H}_{48} \mathrm{~N}_{4} \mathrm{O}_{3} \mathrm{Zn} ;{ }^{1} \mathrm{H}$ NMR (300 MHz, $\left.\mathrm{CDCl}_{3}\right): \delta=10.15$ ( $2 \mathrm{H}, 8$, meso $), 10.06(1 \mathrm{H}, \mathrm{s}$, meso $), 7.93(2 \mathrm{H}, \mathrm{m}), 7.72-$ $7.58(3 \mathrm{H}, \mathrm{m}), 7.08(1 \mathrm{H}, \mathrm{t}), 4.09(8 \mathrm{H}, \mathrm{q}), 3.65(6 \mathrm{H}, \mathrm{s})$, $2.50(6 \mathrm{H}, \mathrm{s}), 1.94(12 \mathrm{H}, \mathrm{m}), 1.76(6 \mathrm{H}, \mathrm{t})$.

The zinc porphyrin 1a was demetalated by washing with $10 \% \mathrm{HCI}$ in dichloromethane to afford the free base $\mathbf{1}$ in quantitative yield. UV-Vis (dichloromethane): $\lambda_{\max }$ (rel. int.) $=403(0.868), 501(0.114), 534(0.070)$, 571 (0.053), 622 (0.022); MS: $m / z=730.5$ for $\mathrm{C}_{48} \mathrm{H}_{50} \mathrm{~N}_{4} \mathrm{O}_{3} ;{ }^{1} \mathrm{H}$ NMR $\left(300 \mathrm{MHz}, \mathrm{CDCl}_{3}\right): \delta=10.14$ ( $2 \mathrm{H}$, s, meso ), $9.96(1 \mathrm{H}, \mathrm{s}$, meso $), 7.93(1 \mathrm{H}, \mathrm{d}), 7.78$ (1 $\mathrm{H}, \mathrm{d}), 7.71(1 \mathrm{H}, \mathrm{d}), 7.64(1 \mathrm{H}, \mathrm{d}), 7.59(1 \mathrm{H}, \mathrm{t}), 7.11$ (1 $\mathrm{H}, \mathrm{t}), 4.08-3.92(8 \mathrm{H}, \mathrm{m}), 3.62(6 \mathrm{H}, \mathrm{s}), 2.47(6 \mathrm{H}, \mathrm{s})$, $1.93(6 \mathrm{H}, \mathrm{s}), 1.86(6 \mathrm{H}, \mathrm{t}), 1.71(6 \mathrm{H}, \mathrm{t}),-3.26(2 \mathrm{H}, \mathrm{br}$, $\mathrm{NH})$.

\subsubsection{Xanthene-porphyrin carboxamide ( 8 )}

To porphyrin $1(25 \mathrm{mg}, 0.03 \mathrm{mmol})$ in dry dichloromethane $(10 \mathrm{ml})$ was added $\mathrm{SOCl}_{2}(0.5 \mathrm{ml})$ and the solution was refluxed for $1 \mathrm{~h}$ under argon atmosphere before the solvent was removed. The residue was dissolved in dry dichloromethane and $\mathrm{NH}_{3}$ gas was bubbled through the solution for $2 \mathrm{~min}$. The solution was washed with water and evaporated to afford a purple solid of 8 ( $25 \mathrm{mg}, 98 \%)$. UV-Vis (dichloromethane): $\lambda_{\max }($ rel. int. $)=402(1.134), 502(0.119), 535$ (0.071), 570 (0.066), 623 (0.038); MS: $m / z=729.5$ for $\mathrm{C}_{48} \mathrm{H}_{51} \mathrm{~N}_{5} \mathrm{O}_{2} ;{ }^{1} \mathrm{H}$ NMR (300 MHz, $\left.\mathrm{CDCl}_{3}\right): \delta=10.16(2$ $\mathrm{H}$, s, meso $), 10.00(1 \mathrm{H}, \mathrm{s}$, meso $), 7.94-7.88(2 \mathrm{H}, \mathrm{m})$, 7.65-7.57 (3 H, m), $7.03(1 \mathrm{H}, \mathrm{t}), 4.29$ (2 H, br, amide NH) 4.12-3.93 (8 H, m), $3.64(6 \mathrm{H}, \mathrm{s}), 2.51(6 \mathrm{H}, \mathrm{s}), 1.90$ $(6 \mathrm{H}, \mathrm{s}), 1.85(6 \mathrm{H}, \mathrm{t}), 1.72(6 \mathrm{H}, \mathrm{t}),-3.24(2 \mathrm{H}, \mathrm{br}, \mathrm{NH})$. Iron was inserted into the porphyrin 8 to give the iron(III) complex $8 \mathbf{a}$ by the standard $\mathrm{FeSO}_{4}$ method. UV-Vis (dichloromethane): $\lambda_{\max }$ (rel. int.) $=385$ (0.928), 503 (0.088), 534 (0.077), 639 (0.036); MS: m/ $z=783.1\left[M^{+}-\mathrm{Cl}\right]$ for $\mathrm{C}_{48} \mathrm{H}_{49} \mathrm{~N}_{5} \mathrm{O}_{2} \mathrm{ClFe}$.

\subsubsection{Xanthene-porphyrin hydrazide (9)}

To porphyrin $1(25 \mathrm{mg}, 0.03 \mathrm{mmol})$ in dry dichloromethane $(10 \mathrm{ml})$ was added $\mathrm{SOCl}_{2}(0.5 \mathrm{ml})$ and the solution was refluxed for $1 \mathrm{~h}$ under argon atmosphere before the solvent was removed. The residue was dissolved in dry dichloromethane and an excess of anhydrous hydrazine $(10 \mathrm{ml}, 0.29 \mathrm{mmol})$ was added. The solution was stirred for $10 \mathrm{~min}$ before being washed with water. The solvent was evaporated to afford a purple solid (25 mg, 98\%) of 9. UV-Vis (dichloromethane): $\lambda_{\max }($ rel. int. $)=404$ (1.003), 503 (0.082), 536 (0.045), 570 (0.044), 623 (0.019); MS: $m / z=744.2$ for $\mathrm{C}_{48} \mathrm{H}_{52} \mathrm{~N}_{6} \mathrm{O}_{2} ;{ }^{1} \mathrm{H}$ NMR (300 MHz, $\left.\mathrm{CDCl}_{3}\right): \delta=10.17(2$ $\mathrm{H}, \mathrm{s}$, meso $), 9.99(1 \mathrm{H}, \mathrm{s}$, meso $), 7.93(2 \mathrm{H}, \mathrm{d}), 7.59(3 \mathrm{H}$, $\mathrm{m}), 7.05(1 \mathrm{H}, \mathrm{t}), 5.23(1 \mathrm{H}$, br, hydrazide $\mathrm{NH}) 4.04(8 \mathrm{H}$, m), $3.64(6 \mathrm{H}, \mathrm{s}) .2 .49(6 \mathrm{H}, \mathrm{s}), 1.89(6 \mathrm{H}, \mathrm{s}), 1.88(6 \mathrm{H.t})$, $1.73(6 \mathrm{H}, \mathrm{t}),-0.91(2 \mathrm{H}$, hydrazide $\mathrm{NH}),-3.18(1 \mathrm{H}$, br, $\mathrm{NH}),-3.23(1 \mathrm{H}, \mathrm{br}, \mathrm{NH})$.

A mixture of porphyrin $9(25 \mathrm{mg}, 0.03 \mathrm{mmol})$ in chloroform $(20 \mathrm{ml})$ and zinc acetate $(75 \mathrm{mg}, 0.34 \mathrm{mmol})$ in methanol $(5 \mathrm{ml})$ was refluxed for $45 \mathrm{~min}$ before being washed with water. The solvent was evaporated to give $26.5 \mathrm{mg}(98 \%)$ of the zinc complex 9a. UV-Vis (dichloromethane): $\lambda_{\max }$ (rel. int.) $=415$ (1.055), 543 (0.056), $580 \quad$ (0.033); MS: $m / z=808.1$ for$\mathrm{C}_{48} \mathrm{H}_{50} \mathrm{~N}_{6} \mathrm{O}_{2} \mathrm{Zn}:{ }^{1} \mathrm{H}$ NMR (300 $\left.\mathrm{MHz}, \mathrm{CDCl}_{3}\right): \delta=$ $10.06(2 \mathrm{H}, \mathrm{s}$, meso $), 10.01(1 \mathrm{H}, \mathrm{s}$, meso $), 8.69(1 \mathrm{H}$, d), $7.85(1 \mathrm{H}, \mathrm{d}), 7.71(1 \mathrm{H}, \mathrm{t}), 7.35(1 \mathrm{H}, \mathrm{d}), 7.03(1 \mathrm{H}$, d), $6.70(1 \mathrm{H}, \mathrm{t}), 4.10(6 \mathrm{H}, \mathrm{m}), 3.85(2 \mathrm{H}, \mathrm{q}), 3.62(6 \mathrm{H}$, s), $2.56(6 \mathrm{H}, 8), 2.48(1 \mathrm{H}$, br, hydrazide $\mathrm{NH}), 1.91(6 \mathrm{H}$, t), $1.74(6 \mathrm{H}, \mathrm{s}), 1.73(6 \mathrm{H}, \mathrm{t}),-1.91(2 \mathrm{H}, \mathrm{br}$, hydrazide $\mathrm{NH})$.

\subsubsection{Xanthene-porphyrin (1-adamantanamide (10) and $\mathrm{Zn}(\mathrm{II})$ complex (10a)}

Prepared in the same manner as described above from the porphyrin acid chloride and 1-adamantanamine; yield: $87 \%$. The insertion of zinc using zinc acetate was quantitative. UV-Vis (dichloromethane): $\lambda_{\max }$ (rel. int.) $=403$ (0.926), 503 (0.075), 536 (0.040) 571 (0.037), 623 (0.014); MS: $m / z=808.1$ for $\mathrm{C}_{58} \mathrm{H}_{62} \mathrm{~N}_{5} \mathrm{O}_{2} \mathrm{Zn}$.

\subsection{Synthesis of the amidinelamidinium salt (14)}

\subsubsection{5-Hydroxymethyl-4-\{[5,5'-bis(ethoxycarbonyl)- 4,4'-diehyl-3,3'-dimethyl-2,2'-dipyrryl]methyl $\}$ - (9,9- dimethyl)xanthene}

The aldehyde 4 (610 mg, $1 \mathrm{mmol})$ was dissolved in ethanol $(20 \mathrm{ml})$ and sodium borohydride $(30 \mathrm{mg}$ in minimum quantity of water) was added. The mixture was stirred at r.t. for $20 \mathrm{~min}$. A solution of $\mathrm{NaOH}(20 \%$ solution, $0.5 \mathrm{ml}$ ) was added, and the mixture was heated on a steam bath for $5 \mathrm{~min}$ before being poured into ice water. The resultant white solid was collected by filtration to afford $575 \mathrm{mg}(94 \%)$ of the reduced dipyrrylmethane. M.p. $88-90^{\circ} \mathrm{C}$; MS: $m / z=611.3$ for $\mathrm{C}_{37} \mathrm{H}_{44} \mathrm{~N}_{2} \mathrm{O}_{6} ;{ }^{1} \mathrm{H}$ NMR $\left(300 \mathrm{MHz}, \mathrm{CDCl}_{3}\right): \delta=8.24(2$ $\mathrm{H}, \mathrm{br}, \mathrm{NH}), 7.44(1 \mathrm{H}, \mathrm{d}), 7.36(2 \mathrm{H}, \mathrm{d}), 7.09-7.00(2 \mathrm{H}$, $\mathrm{m}), 6.71(1 \mathrm{H}, \mathrm{d}), 6.09(1 \mathrm{H}, \mathrm{s}$, methane $\mathrm{CH}), 5.91(2 \mathrm{H}$, d, $\left.\mathrm{CH}_{2} \mathrm{O}\right), 5.51(1 \mathrm{H}, \mathrm{s}, \mathrm{OH}), 4.22(4 \mathrm{H}, \mathrm{q}), 2.70(4 \mathrm{H}, \mathrm{q})$, $1.76(6 \mathrm{H}, \mathrm{s}), 1.61(6 \mathrm{H}, \mathrm{s}), 1.27(6 \mathrm{H}, \mathrm{t}), 1.10(6 \mathrm{H}, \mathrm{t})$. 
4.2.2. 5-[5-Hydroxymethyl-4-(9,9-dimethyl)xanthenyl]2,8,13,17-tetraethyl-3,7,12,18-tetramethylpophyrin (11)

The above dipyrrylmethane $(600 \mathrm{mg}, 0.98 \mathrm{mmol})$ was added to ethanol $(20 \mathrm{ml})$ containing sodium hydroxide solutiuon $(50 \%, 1 \mathrm{ml})$. The mixture was refluxed for $8 \mathrm{~h}$ under argon before the solvent being removed. The residue was taken up in water $(10 \mathrm{ml})$ and neutralized with acetic acid, the precipitated white solid was isolated by filtration to give $525 \mathrm{mg}(96 \%)$ of the diacid. This diacid $(500 \mathrm{mg}, 0.90 \mathrm{mmol}$ ) was decarboxylated by heating in ethanolamine $(5 \mathrm{ml})$ under reflux for $1 \mathrm{~h}$. The yellow solution was poured into ice water, the resultant light yellow solid was collected by filtration to afford $400 \mathrm{mg}(95 \%)$ of the $\alpha$-free dipyrrylmethane. M.p. $78-$ $79{ }^{\circ} \mathrm{C}$; MS: $m / z=468.3$ for $\mathrm{C}_{31} \mathrm{H}_{36} \mathrm{~N}_{2} \mathrm{O}_{2} ;{ }^{1} \mathrm{H}$ NMR (300 $\left.\mathrm{MHz}, \mathrm{CDCl}_{3}\right): \delta=8.71(2 \mathrm{H}, \mathrm{br}, \mathrm{NH}), 7.44(1 \mathrm{H}, \mathrm{d})$, 7.37-7.32 (3 H, m), 7.07-7.00 (2 H, m), $6.34(2 \mathrm{H}, \mathrm{s})$, $6.28(1 \mathrm{H}, \mathrm{s}$, methane $\mathrm{CH}), 3.42(2 \mathrm{H}, \mathrm{q}), 2.37(2 \mathrm{H}, \mathrm{q})$, $1.80\left(2 \mathrm{H}, \mathrm{br}, \mathrm{CH}_{2} \mathrm{O}\right), 1.73(6 \mathrm{H}, \mathrm{s}), 1.57(6 \mathrm{H}, \mathrm{s}), 1.16(3$ $\mathrm{H}, \mathrm{t}), 1.12(3 \mathrm{H}, \mathrm{t})$.

The $\alpha$-free dipyrrylmethane (400 $\mathrm{mg}, 0.85 \mathrm{mmol}$ ) and 5,5'-diformyl-3,3'-diethyl-4,4' -dimethyl-2,2' -dipyrrylmethane (7) [22] (245 mg, $0.85 \mathrm{mmol})$ was dissolved in dry methanol $(60 \mathrm{ml})$ under argon atmosphere. To this mixture $70 \%$ perchloric acid $(0.5 \mathrm{ml})$ was added and solution was stirred at r.t. under argon with exclusion of light for $16 \mathrm{~h}$. A solution of $\mathrm{NaOAc}(0.5 \mathrm{~g})$ in methanol $(10 \mathrm{ml})$ was added to the solution, followed by another solution of $o$-chloranil $(190 \mathrm{mg})$ in methanol $(5 \mathrm{ml})$. After $1 \mathrm{~h}$ the solvent was removed and the residue was taken up in $\mathrm{CH}_{2} \mathrm{Cl}_{2}(20 \mathrm{ml})$ and a solution of zinc acetate $(300 \mathrm{mg})$ in methanol $(5 \mathrm{ml})$ was added. After being stirred for $3 \mathrm{~h}$, the solvent was evaporated and the residue was purified by chromatography (silica gel, $\mathrm{CH}_{2} \mathrm{Cl}_{2}$ ) to give $325 \mathrm{mg}(49 \%)$ pure product of the zinc complex of porphyrin 11. UV-Vis $\left(\mathrm{CH}_{2} \mathrm{Cl}_{2}\right): \lambda_{\max }$ (rel. int.) $=404$ (0.731), 533 (0.037), 571 (0.034); MS: $m /$ $z=778.5$ for $\mathrm{C}_{48} \mathrm{H}_{48} \mathrm{~N}_{4} \mathrm{O}_{2} \mathrm{Zn}$; ${ }^{1} \mathrm{H}$ NMR $(300 \mathrm{MHz}$, $\left.\mathrm{CDCl}_{3}\right): \delta=10.16(2 \mathrm{H}, \mathrm{s}$, meso $), 9.97(1 \mathrm{H}, \mathrm{s}$, meso $)$, $7.91(1 \mathrm{H}, \mathrm{d}), 7.79(1 \mathrm{H}, \mathrm{d}), 7.53(1 \mathrm{H}, \mathrm{t}), 7.39(1 \mathrm{H}, \mathrm{d})$, $6.92(1 \mathrm{H}, \mathrm{t}), 6.71(1 \mathrm{H}, \mathrm{d}), 4.01(8 \mathrm{H}, \mathrm{q}), 3.62(6 \mathrm{H}, \mathrm{s})$, $2.69\left(2 \mathrm{H}, \mathrm{br}, \mathrm{CH}_{2} \mathrm{O}\right), 2.51(6 \mathrm{H}, \mathrm{s}), 1.89(6 \mathrm{H}, \mathrm{s}), 1.85(6$ $\mathrm{H}, \mathrm{t}), 1.70(6 \mathrm{H}, \mathrm{t})$.

The zinc porphyrin was demetaleted by washing with $10 \% \mathrm{HCl}$ in $\mathrm{CH}_{2} \mathrm{Cl}_{2}$ to afford $\mathbf{1 1}$ in quantitative yield. UV/Vis $\left(\mathrm{CH}_{2} \mathrm{Cl}_{2}\right): \lambda_{\max }$ (rel. int.) $=403$ (1.105), 502 (0.090), 536 (0.043), 570 (0.040), 624 (0.016); MS: $m /$ $z=716.1$ for $\mathrm{C}_{48} \mathrm{H}_{52} \mathrm{~N}_{4} \mathrm{O}_{2} ;{ }^{1} \mathrm{H}$ NMR $(300 \mathrm{MHz}$, $\left.\mathrm{CDCl}_{3}\right): \delta=10.16(2 \mathrm{H}, \mathrm{s}$, meso $), 9.98(1 \mathrm{H}, \mathrm{s}$, meso $)$, $7.90(1 \mathrm{H}, \mathrm{d}), 7.77(1 \mathrm{H}, \mathrm{d}), 7.52(1 \mathrm{H}, \mathrm{t}), 7.42(1 \mathrm{H}, \mathrm{d})$, $6.92(1 \mathrm{H}, \mathrm{t}), 6.72(1 \mathrm{H}, \mathrm{d}), 4.08(4 \mathrm{H}, \mathrm{q}), 4.00(4 \mathrm{H}, \mathrm{q})$, $3.64(6 \mathrm{H}, \mathrm{s}), 2.67\left(2 \mathrm{H}, \mathrm{d}, \mathrm{CH}_{2} \mathrm{O}\right), 2.53(6 \mathrm{H}, \mathrm{s}), 1.90(6$ $\mathrm{H}, \mathrm{s}), 1.87(6 \mathrm{H}, \mathrm{t}), 1.73(6 \mathrm{H}, \mathrm{t}), 0.83(1 \mathrm{H}, \mathrm{t}, \mathrm{OH}),-$ $3.17(2 \mathrm{H}, \mathrm{br}, \mathrm{NH})$.

\subsubsection{5-[5-Formyl-4-(9,9-dimethyl) xanthenyl]-} 2,8,13,17-tetraethyl-3,7,12,18-tetramethylporphyrin (12)

Xanthene alcohol porphyrin $11(120 \mathrm{mg}, 0.17 \mathrm{mmol})$ was dissolved in pyridine $(5 \mathrm{ml})$ and was added dropwise to a pyridine solution $(15 \mathrm{ml})$ of $\mathrm{CrO}_{3}(150 \mathrm{mg})$. The mixture was stirred at r.t. for $7 \mathrm{~h}$ before being poured into water $(100 \mathrm{ml})$. The product was extracted into

Table 1

Summary of X-ray crystallographic data

\begin{tabular}{|c|c|c|c|c|c|}
\hline & 1a & $8 a$ & 9a & 10a. $\mathrm{CHCl}_{3}$ & $14 a \cdot 1 / 2(n-h e x a n e)$ \\
\hline Empirical formula & $\mathrm{C}_{48} \mathrm{H}_{50} \mathrm{~N}_{4} \mathrm{O}_{4} \mathrm{Zn}$ & $\mathrm{C}_{48} \mathrm{H}_{49} \mathrm{ClFeN}_{5} \mathrm{O}_{2}$ & $\mathrm{C}_{48} \mathrm{H}_{50} \mathrm{~N}_{6} \mathrm{O}_{2} \mathrm{Zn}$ & $\mathrm{C}_{59} \mathrm{H}_{63} \mathrm{Cl}_{3} \mathrm{~N}_{5} \mathrm{O}_{2} \mathrm{Zn}$ & $\mathrm{C}_{53} \mathrm{H}_{64} \mathrm{~N}_{6} \mathrm{O}_{3} \mathrm{Zn}$ \\
\hline Formula weight & 812.32 & 819.24 & 806.33 & 1045.91 & 898.50 \\
\hline Space group & Pnma & Pnma & Ccm $2_{1}$ & Pbca & $P 2_{1} / c$ \\
\hline \multicolumn{6}{|l|}{ Unit cell dimensions } \\
\hline$a(\AA)$ & $20.985(5)$ & $21.110(4)$ & $23.420(5)$ & $20.229(4)$ & $9.1595(12)$ \\
\hline$b(\AA)$ & $16.741(6)$ & $16.682(3)$ & $33.699(9)$ & $40.363(8)$ & $32.884(7)$ \\
\hline$c(\AA)$ & $11.707(4)$ & $11.9539(20)$ & $20.564(4)$ & $13.046(3)$ & $16.365(4)$ \\
\hline$\alpha\left({ }^{\circ}\right)$ & 90.0 & 90.0 & 90.0 & 90.0 & 90.0 \\
\hline$\beta\left(^{\circ}\right)$ & 90.0 & 90.0 & 90.0 & 90.0 & $103.018(20)$ \\
\hline$\gamma\left({ }^{\circ}\right)$ & 90.0 & 90.0 & 90.0 & 90.0 & 90.0 \\
\hline$V\left(\AA^{3}\right)$ & $4112.8(23)$ & $4209.6(13)$ & $16229(6)$ & $10652(4)$ & $4802.4(17)$ \\
\hline$Z$ & 4 & 4 & 16 & 8 & 4 \\
\hline$\rho_{\text {calc }}\left(\mathrm{g} \mathrm{cm}^{-3}\right)$ & 1.312 & 1.293 & 1.323 & 1.304 & 1.243 \\
\hline$\mu\left(\mathrm{mm}^{-1}\right)$ & $($ Mo K $\alpha) 0.7107$ & $($ Mo K $\alpha) 0.7107$ & $($ Mo K $\alpha) 0.7107$ & $(\mathrm{Cu} \mathrm{K} \alpha) 1.5418$ & $(\mathrm{Cu} \mathrm{K} \alpha) 1.5418$ \\
\hline$\theta$ Limits $\left({ }^{\circ}\right)$ & $7.0-12.24$ & $6.81-11.50$ & $10.00-12.50$ & $20.00-25.00$ & $15.00-22.15$ \\
\hline Total no. of data & 2784 & 3827 & 7491 & 8650 & 6937 \\
\hline No. of unique data & 2784 & 3827 & 7491 & 6696 & 6937 \\
\hline No. of parameters & 289 & 290 & 1091 & 632 & 570 \\
\hline$R(\%)^{\mathrm{a}}$ & 9.6 & 5.1 & 6.9 & 6.4 & 5.8 \\
\hline$w R^{2}(\%)^{\mathrm{b}}$ & 10.8 & 5.0 & 6.0 & 6.6 & 6.3 \\
\hline Max, min peaks $\left(\mathrm{e} \AA^{-3}\right)$ & $0.95,-0.70$ & $0.39,-0.38$ & $0.58,-0.76$ & $0.42,-0.40$ & $0.52,-0.37$ \\
\hline
\end{tabular}

${ }^{\mathrm{a}} R=\Sigma|| F_{\mathrm{o}}|-| F_{\mathrm{c}}|/ \Sigma| F_{\mathrm{o}} \mid$.

b $w R^{2}=\left\{\Sigma\left[w\left(F_{\mathrm{o}}^{2}-F_{\mathrm{c}}^{2}\right)^{2}\right] / \Sigma\left[w\left(F_{\mathrm{o}}^{2}\right)^{2}\right]\right\}^{1 / 2}$. 
$\mathrm{CH}_{2} \mathrm{Cl}_{2}$ and purified by chromatography (silica gel, $\mathrm{CH}_{2} \mathrm{Cl}_{2}$ ) to afford $98 \mathrm{mg}(82 \%)$ of $\mathbf{1 2}$. UV-Vis $\left(\mathrm{CH}_{2} \mathrm{Cl}_{2}\right): \lambda_{\max }$ (rel. int.) $=404$ (1.115), 501 (0.088), 536 (0.044), 574 (0.041), 624 (0.016); MS: $m / z=714$ for $\mathrm{C}_{48} \mathrm{H}_{50} \mathrm{~N}_{4} \mathrm{O}_{2} ;{ }^{1} \mathrm{H}$ NMR (300 MHz, $\left.\mathrm{CDCl}_{3}\right): \delta=$ $10.14(2 \mathrm{H}$, s, meso $), 9.96(1 \mathrm{H}$, s, meso $), 7.91(1 \mathrm{H}$, d), $7.80(1 \mathrm{H}, \mathrm{d}), 7.77(1 \mathrm{H}, \mathrm{s}, \mathrm{CHO}), 7.71(1 \mathrm{H}, \mathrm{d}), 7.56$ $(1 \mathrm{H}, \mathrm{t}), 7.37(1 \mathrm{H}, \mathrm{d}), 7.07(1 \mathrm{H}, \mathrm{t}), 4.07(4 \mathrm{H}, \mathrm{q}), 3.96(4$ $\mathrm{H}, \mathrm{q}), 3.63(6 \mathrm{H}, \mathrm{s}), 2.47(6 \mathrm{H}, \mathrm{s}), 1.89(6 \mathrm{H}, \mathrm{s}), 1.86(6 \mathrm{H}$, t), $1.63(6 \mathrm{H}, \mathrm{t}),-3.16(2 \mathrm{H}, \mathrm{br}, \mathrm{NH})$.

\subsubsection{5-[5-Cyano-4-(9,9-dimethyl) xanthenyl]-}

2,8,13,17-tetraethyl-3,7,12,18-tetramethylporphyrin (13)

To a formic acid solution of the porphyrin aldehyde 12 (90 $\mathrm{mg}, 0.13 \mathrm{mmol}$ ) was added hydroxylamine hydrochloride $(11 \mathrm{mg}, 0.16 \mathrm{mmol})$. The mixture was refluxed overnight and then poured into ice water. The solution was neutralized with $5 \% \mathrm{NaOH}$ solution. The product was extracted into $\mathrm{CH}_{2} \mathrm{Cl}_{2}$ and purified by chromatography (silica gel, $\mathrm{CH}_{2} \mathrm{Cl}_{2}$ ) to give $85 \mathrm{mg}$ $(95 \%)$ of 13. UV-Vis $\left(\mathrm{CH}_{2} \mathrm{Cl}_{2}\right): \lambda_{\max }$ (rel. int.) $=400$ (1.214), 502 (0.104), 537 (0.054), 570 (0.050), 624 (0.014); IR $v_{\mathrm{C}=\mathrm{N}} 2232 \mathrm{~cm}^{-1}$; MS: $m / z=711.3$ for $\mathrm{C}_{48} \mathrm{H}_{49} \mathrm{~N}_{5} \mathrm{O}$; ${ }^{1} \mathrm{H}$ NMR $\left(300 \mathrm{MHz}, \mathrm{CDCl}_{3}\right): \delta=10.12(2 \mathrm{H}, \mathrm{s}$, meso $)$, $9.92(1 \mathrm{H}, \mathrm{s}$, meso $), 7.86(1 \mathrm{H}, \mathrm{d}), 7.71(1 \mathrm{H}, \mathrm{d}), 7.67(1$ $\mathrm{H}, \mathrm{d}), 7.52(1 \mathrm{H}, \mathrm{t}), 7.11(1 \mathrm{H}, \mathrm{d}), 7.04(1 \mathrm{H}, \mathrm{t}), 4.05(4 \mathrm{H}$, q), $3.97(4 \mathrm{H}, \mathrm{q}), 3.62(6 \mathrm{H}, \mathrm{s}), 2.45(6 \mathrm{H}, \mathrm{s}), 1.87(6 \mathrm{H}, \mathrm{s})$, $1.85(6 \mathrm{H}, \mathrm{t}), 1.73(6 \mathrm{H}, \mathrm{t}),-3.18(2 \mathrm{H}, \mathrm{br}, \mathrm{NH})$.

\subsubsection{5-[5-Amidino-4-(9,9-dimethyl)xanthenyl]-}

2,8,13,17-tetraethyl-3,7,12,18-tetramethylporphyrin (14)

To prevent aluminum insertion into the porphyrin during the next step of reaction, the nickel complex of the cyano porphyrin $\mathbf{1 3}$ was prepared first by heating with $\mathrm{Ni}(\mathrm{II})(\mathrm{OAc})_{2}$ in $\mathrm{DMF}$ at $120^{\circ} \mathrm{C}$ for $1 \mathrm{~h}$, followed by evaporation of the solvent, washing with $\mathrm{H}_{2} \mathrm{O}$ and extracting into $\mathrm{CH}_{2} \mathrm{Cl}_{2}$. The nickel complex of $\mathbf{1 3}$ (80 $\mathrm{mg}, 0.1 \mathrm{mmol})$ was dissolved in dry toluene $(10 \mathrm{ml})$ under an argon atmosphere and $1 \mathrm{M}$ toluene solution of methylaluminum chloroamide $(2 \mathrm{ml}, 2 \mathrm{mmol})$ was added. The mixture was stirred at $80{ }^{\circ} \mathrm{C}$ for $40 \mathrm{~h}$ under argon before solvent being removed under vacuum. The residue was dissolved in $\mathrm{CH}_{2} \mathrm{Cl}_{2}$ and purified by chromatography (silica gel $\mathrm{CH}_{2} \mathrm{Cl}_{2}$ :methanol $=98: 2$ ) to give a pure product. Nickel was removed by washing with sulfuric acid in $\mathrm{CH}_{2} \mathrm{Cl}_{2}$ to afford $60 \mathrm{mg}(74 \%)$ of 14. UV-Vis $\left(\mathrm{CH}_{2} \mathrm{Cl}_{2}\right): \lambda_{\max }$ (rel. int.) $=403(1.359), 504$ (0.107), 538 (0.056), 570 (0.053), 623 (0.018); MS: $\mathrm{m} / \mathrm{z}=$ 728.3 for $\mathrm{C}_{48} \mathrm{H}_{52} \mathrm{~N}_{6} \mathrm{O} ;{ }^{1} \mathrm{H}$ NMR (300 $\mathrm{MHz}, \mathrm{CDCl}_{3}$ ): $\delta=10.10(2 \mathrm{H}, \mathrm{s}$, meso $), 9.95(1 \mathrm{H}, \mathrm{s}$, meso $), 7.84(1 \mathrm{H}$, d), $7.79(1 \mathrm{H}, \mathrm{d}), 7.53(1 \mathrm{H}, \mathrm{t}), 7.39(1 \mathrm{H}, \mathrm{d}), 7.05(1 \mathrm{H}$, d), $6.86(1 \mathrm{H}, \mathrm{t}), 4.03(6 \mathrm{H}, \mathrm{q}), 3.92(2 \mathrm{H}, \mathrm{q}), 3.58(6 \mathrm{H}, \mathrm{s})$, $2.43(6 \mathrm{H}, \mathrm{s}), 2.17(3 \mathrm{H}, \mathrm{br}$, amidine $\mathrm{NH}), 1.84(6 \mathrm{H}, \mathrm{t})$, $1.75(6 \mathrm{H}, \mathrm{s}), 1.67(6 \mathrm{H}, \mathrm{t}),-3.30(2 \mathrm{H}, \mathrm{br}, \mathrm{NH})$.

The zinc complex 14a was formed by heating porphyrin $14(25 \mathrm{mg}, 0.03 \mathrm{mmol})$ in chloroform $(20 \mathrm{ml})$ with a solution of zinc acetate $(75 \mathrm{mg}, 0.34 \mathrm{mmol})$ in methanol $(5 \mathrm{ml})$ under refluxed for $45 \mathrm{~min}$ before being washed with water. The organic solvent was evaporated to give $26.5 \mathrm{mg}(98 \%)$. UV-Vis $\left(\mathrm{CH}_{2} \mathrm{Cl}_{2}\right): \lambda_{\max }$ (rel. int.) $=416$ (1.164), 544 (0.064), 580 (0.032); MS: $m / z=$ 792.1 for $\mathrm{C}_{48} \mathrm{H}_{50} \mathrm{~N}_{6} \mathrm{OZn} ;{ }^{1} \mathrm{H}$ NMR (300 $\mathrm{MHz}, \mathrm{CDCl}_{3}$ ): $\delta=9.97(2 \mathrm{H}, \mathrm{s}$, meso $), 9.92(1 \mathrm{H}, \mathrm{s}$, meso $), 7.84(1 \mathrm{H}, \mathrm{d})$, $7.81(1 \mathrm{H}, \mathrm{d}), 7.51(1 \mathrm{H}, \mathrm{t}), 7.50(1 \mathrm{H}, \mathrm{d}), 6.66(1 \mathrm{H}, \mathrm{t})$, $6.15(1 \mathrm{H}, \mathrm{d}), 4.17(2 \mathrm{H}, \mathrm{br}$, amidine $\mathrm{NH}), 4.04(4 \mathrm{H}, \mathrm{q})$, $3.95(2 \mathrm{H}, \mathrm{q}), 3.77(2 \mathrm{H}, \mathrm{q}), 3.57(6 \mathrm{H}, \mathrm{s}), 2.34(6 \mathrm{H}, \mathrm{s})$, $1.82(6 \mathrm{H}, \mathrm{t}), 1.81(6 \mathrm{H}, \mathrm{s}), 1.62(6 \mathrm{H}, \mathrm{t}),-2.43(3 \mathrm{H}, \mathrm{s}$, acetate $\mathrm{CH}_{3}$ ).

\subsection{X-ray data collection and structure refinement}

All crystals were grown by slow evaporation of chloroform/hexane solutions. Data were collected at $293 \mathrm{~K}$ and structures were solved by direct methods using NRCVAX program package. All non-hydrogen atoms were refined anisotropically. The hydrogen atoms of interest were located from difference map and refined positionally when appropriate. The crystallographic data for the five structures are summarized in Table 1.

\section{Supplementary material}

Crystallographic data for the structural analysis have been deposited with the Cambridge Crystallographic Data Centre, CCDC Nos. 205655-205659 for 1a,8a, 14a, 9a and 10a. Copies of this information may be obtained free of charge from The Director, CCDC, 12 Union Road, Cambridge, CB2 1EZ, UK (fax: +44-1223-336033; e-mail: deposit@ccdc.cam.ac.uk or www: http:// www.ccdc.cam.ac.uk).

\section{Acknowledgements}

This work was supported by NIH grant GM36520.

\section{References}

[1] J.H. Dawson, Science 240 (1988) 433.

[2] T.L. Poulos, Adv. Inorg. Biochem. 7 (1998) 1.

[3] I. Schlichting, J. Berendzen, K. Chu, A.M. Stock, S.A. Maves, D.E. Benson, R.M. Sweet, D. Ringo, G.A. Petsko, S.G. Sligar, Science 287 (2000) 1615.

[4] (a) S. Ferguson-Miller, G.T. Babcock, Chem. Rev. 96 (1996) 2889 ;

(b) G.T. Babcock, Proc. Natl. Acad. Sci. USA 96 (1999) 12971.

[5] V. Fülöp, J.W.B. Moir, S.J. Ferguson, J. Hajdu, Cell 81 (1995) 369.

[6] S. Yoshikawa, K. Shinzawa-Itoh, R. Nakashima, R. Yaono, E. Yamashita, N. Inoue, M. Yao, M.J. Fei, C.P. Libeu, T. Mizushima, H. Yamaguchi, T. Tomizaki, T. Tsukihara, Science 280 (1998) 1723. 
[7] B.R. Crane, L.M. Siegel, E.D. Getzoff, Science 270 (1995) 59.

[8] (a) C.K. Chang, M.P. Kondylis, J. Chem. Soc., Chem. Commun. (1986) 316.;

(b) C.K. Chang, G. Avilés, N. Bag, J. Am. Chem. Soc. 116 (1994) 12127.

[9] C.K. Chang, Y. Liang, G. Avilés, S.M. Peng, J. Am. Chem. Soc. 117 (1995) 4191.

[10] M. Matsu-ura, F. Tani, S. Nakayama, N. Nakamura, Y. Naruta, Angew. Chem., Int. Ed. Engl. 39 (2000) 1989.

[11] C.Y. Yeh, C.J. Chang, D.G. Nocera, J. Am. Chem. Soc. 123 (2001) 1513

[12] C. Turró, C.K. Chang, G.E. Leroi, R.I. Cuckier, D.G. Nocera, J. Am. Chem. Soc. 114 (1992) 4013.

[13] J.P. Kirby, N.A. van Dantzig, C.K. Chang, D.G. Nocera, Tetrahedron Lett. 36 (1995) 3477.
[14] Y. Deng, J.A. Roberts, S.M. Peng, C.K. Chang, D.C. Nocera, Angew. Chem., Int. Ed. Engl. 36 (1997) 2124.

[15] B. Guo, MSc Dissertation, Michigan State University, E. Lansing, MI, 1996.

[16] J.S. Nowick, P. Ballester, F. Ebmeyer, J. Rebek, J. Am. Chem. Soc. 112 (1990) 8902.

[17] G. Shipps, J. Rebek, Tetrahedron Lett. 35 (1994) 6823.

[18] C.J. Chang, Y. Deng, A.F. Heyduk, C.K. Chang, D.G. Nocera, Inorg. Chem. 39 (2000) 959.

[19] I. Abdalmuhdi, C.K. Chang, J. Org. Chem. 50 (1985) 411.

[20] J. Levin, E. Turos, S.M. Weinreb, Synth. Comm. 12 (1982) 989.

[21] N. Bag, S.S. Chern, S.M. Peng, C.K. Chang, J. Inorg. Chem. 34 (1995) 753.

[22] R. Chong, P.S. Clezy, A.J. Liepa, A.W. Nichol, Aust. J. Chem. 22 (1969) 229. 